\title{
COALIZÕES ELEITORAIS E AJUSTE FISCAL NOS ESTADOS BRASILEIROS*
}

\section{Celina Souza}

\section{Introdução}

Em países federais que retornaram ao voto popular para a escolha dos ocupantes dos cargos no Executivo, e que, simultaneamente, assumiram

* Este artigo é resultado de pesquisa financiada com recursos do CNPq e da Fapesb. Agradeço aos colegas Filomeno Moraes e Herbert Age, pelo fornecimento dos dados eleitorais desagregados do Ceará e do Paraná; a Lara Mesquita, pelo processamento dos dados e pela elaboração dos mapas; a Flávio Fontanelli, pela análise estatística e econométrica; a André Borges, Argelina Figueiredo, Eduardo Marques, Fernando Limongi, Haroldo Torres, Judith Tendler, Maria Hermínia Tavares de Almeida, Natália Sátyro, Paulo Fábio Dantas Neto, Tulia Falleti e aos pareceristas anônimos da RBCS, pelos comentários e sugestões.

Artigo recebido em maio/2006 Aprovado em janeiro/2007 o ajuste fiscal como prioridade, os estados passaram a jogar um papel importante no que se refere ao impacto de políticas restritivas de gasto sobre os resultados eleitorais. No entanto, a maioria das pesquisas tem se concentrado na esfera nacional, focalizando suas instituições políticas e as conseqüências da política federal de ajuste fiscal sobre as demais políticas públicas nacionais. ${ }^{1}$ No entanto, em países federais, em especial naqueles onde os estados detêm parcela considerável da receita e da despesa públicas, é importante analisar, também, o universo estadual. ${ }^{2}$

Este artigo analisa por que e como os estados adotaram a política federal de ajuste fiscal e as repercussões dessa política nos resultados eleitorais do ponto de vista territorial e das características socioeconômicas dos municípios onde votam os eleitores. O objetivo não é investigar o papel desempenhado pelo ajuste fiscal nas preferências dos eleitores, dado que inúmeras variáveis influenciam os resultados eleitorais, mas identificar 
a existência ou não de mudanças nos resultados eleitorais do ponto de vista territorial a partir da adoção de políticas restritivas de gasto. No mesmo veio, não se busca mensurar o impacto eleitoral da política de ajuste fiscal, mas analisar onde as coalizões que implementaram o ajuste fiscal ganharam ou perderam votos do ponto de vista territorial. Essa investigação justifica-se porque, com a redemocratização e o retorno das eleições diretas para governador, é preciso entender melhor a influência de políticas que mudam o status quo sobre a formação de coalizões eleitorais. Isso porque, como subsumido por vários autores, políticas de ajuste fiscal mudariam as relações que se estabelecem entre as coalizões que governam e os eleitores.

Se, do ponto de vista das reformas macroeconômicas, o papel dos estados tem sido mais pesquisado, como se verá adiante, do ponto de vista político ainda conhecemos pouco como funciona o universo político estadual no Brasil. ${ }^{3} \mathrm{Na}$ literatura brasileira, poucos trabalhos focalizam o papel dos estados na produção e na implementação de políticas de ajuste fiscal, embora pesquisas recentes analisem questões fiscais e orçamentárias vis-à-vis a dinâmica política em algumas instâncias estaduais. ${ }^{4}$

Diante disso, existem lacunas na literatura e na pesquisa que precisam ser preenchidas. Uma dessas lacunas refere-se à análise sobre o formato e a operacionalização de políticas públicas estaduais, como a do ajuste fiscal, e sua relação com a formação de coalizões eleitorais de apoio a essa política. Esta pesquisa é uma tentativa de preencher essa lacuna, apoiando-se em dois pilares: (a) na agenda macroeconômica, em especial o ajuste fiscal, para entender as respostas dadas pelos estados à política federal de ajuste fiscal; e (b) na agenda político-eleitoral, para investigar o impacto das políticas de ajuste nos resultados eleitorais.

Este trabalho parte do seguinte problema central: desde a redemocratização e da promulgação da Constituição de 1988, o Brasil passou a ter um sistema político e tributário bastante descentralizado em comparação com o regime anterior e com outros países em desenvolvimento. Assim, o papel das esferas estaduais ganhou maior importância e visibilidade. Apesar disso, após mais de uma década de redemocratização e passados alguns anos de implementação do ajuste fiscal nos estados, não sabemos o impacto dessa política nos resultados eleitorais.

Busca-se, então, aprofundar o entendimento sobre as seguintes questões centrais:

a) Por que os estados brasileiros aderiram às políticas federais restritivas de gasto, uma vez que, em países federais, os estados podem ou não aderir a essas políticas?

b) Por que políticas de ajuste fiscal não afetaram $\mathrm{O}$ apoio dos eleitores às coalizões políticas estaduais que implantaram o ajuste?

Este trabalho questiona a hipótese de alguns autores, principalmente dos chamados brasilianistas, de que a política estadual no Brasil é movida apenas por lógicas clientelistas, pela manutenção de políticas que não afetam o status quo (política tradicional) e pelo uso dos recursos públicos para sustentá-la. ${ }^{5}$ Se essa hipótese fosse verdadeira, políticas de ajuste fiscal seriam impossiveis na esfera estadual, principalmente em estados que abrigam altos contingentes de eleitores pobres. São representativos dessas interpretações trabalhos como os de Ames (1996; 2001), Hagopian (1996), ${ }^{6}$ Mainwaring (1999), Samuels e Mainwaring (2004) e Weyland (1996). A partir da interpretação desses autores, políticas de ajuste fiscal, altamente restritivas de gastos, seriam inviáveis nas esferas estaduais, tendo em vista que os custos dessas práticas são sustentados por recursos públicos, principalmente pelo emprego público.?

Esta pesquisa testa duas hipóteses alternativas. A primeira é a de que políticas restritivas de gasto adotadas por algumas coalizões político-eleitorais estaduais nos anos de 1990 não afetaram as bases territoriais de apoio dos governadores que as implementaram. A segunda é a de que as características socioeconômicas dos eleitores têm pequena ou nenhuma significância no apoio ou na rejeição a políticas de controle fiscal. Se a hipótese de que a política estadual seria tão-somente movida pelo clientelismo fosse verdadeira, poder-se-ia inferir que nos municípios menos urbanizados, com menores receitas per capita e com mais baixos IDHs (Índice de Desenvolvimento Humano), seus eleitores seriam mais suscetíveis ao clientelismo e tenderiam a rejeitar políticas restritivas de gasto. $\mathrm{O}$ 
teste das duas hipóteses alternativas foi feito em três estados selecionados - Bahia, Ceará e Paraná -, comparando o resultado das eleições de 1994, antes do ajuste fiscal, com a de 1998, após o ajuste, e relacionando-os às condições socioeconômicas dos eleitores.

Argumento que a política estadual não é movida por uma única lógica - como a do clientelismo e rejeição a políticas que mudam o status quo -, mas por várias, daí ser possível conciliar políticas restritivas de gasto com vitórias eleitorais. Mesmo não negando a existência de relações de trocas clientelistas nos estados, essas relações, contudo, não impedem a adoção de políticas que mudam o status quo e não reduzem as possibilidades de políticas restritivas de gasto. Os dados e as análises aqui apresentados mostram que os governadores podem conciliar a adoção de políticas restritivas de gasto com vitórias eleitorais. Isso foi possível porque em alguns estados seus dirigentes conseguiram manter suas bases territoriais de apoio tanto na subcoalizão metropolitana como na subcoalizão periférica, nos termos desenvolvidos por Gibson (1997), que serão discutidos adiante. Essas coalizões foram capazes de conciliar o apoio de eleitores dos municípios menos urbanizados, com baixos índices de receita per capita municipal e com baixos IDHs, com os votos de regiões do estado onde as condições socioeconômicas da população são menos precárias.

Apresento, primeiro, os detalhes do ajuste fiscal dos estados, assim como os resultados eleitorais para governador em 1994, 1998 e 2002. As seções seguintes detalham o ajuste nos três estados selecionados e debatem algumas hipóteses sobre os temas da pesquisa. Por fim, dados e análises estatísticas e econométricas sobre o rebatimento territorial do ajuste fiscal nos resultados eleitorais de estados selecionados são utilizados para discutir as hipóteses e o argumento desta pesquisa.

\section{Ajuste fiscal e contexto político-eleitoral nos anos de 1990}

Muitos países em desenvolvimento e em processo de consolidação de seus regimes democráticos estão buscando cumprir duas agendas comuns e simultâneas: uma voltada para a arena macroeconômica e outra, para a arena político-eleitoral. As reformas macroeconômicas visam à inserção desses países na chamada economia globalizada, sendo o controle fiscal parte fundamental dessa agenda. Já a agenda político-eleitoral visa à construção ou reconstrução das instituições democráticas, mas objetiva também a formação de coalizões eleitorais que dêem aos partidos políticos vitórias eleitorais. Essas agendas tentam conciliar uma disciplina fiscal austera com vitórias eleitorais.

Do lado da agenda macroeconômica, o papel dos estados é significativo por ser o Brasil um dos países mais descentralizados do ponto de vista tributário entre os do mundo em desenvolvimento, o que torna os governos estaduais importantes implementadores de políticas públicas e em uma das peças principais do ajuste fiscal. Desse ponto de vista, a importância dos governos subnacionais é inegável: essas esferas arrecadam hoje 32\% dos impostos coletados e, quando incluídas as transferências federais, são responsáveis pela gestão de $43 \%$ dos recursos tributários. ${ }^{8}$ Do lado da despesa, os governos subnacionais respondem por $70 \%$ dos gastos com pessoal e por $78 \%$ dos gastos sociais, excluindo a seguridade social (Afonso, 2006). Apesar das recentes medidas de redução da descentralização tributária, o papel dos estados e dos municípios continua significativo no contexto das contas públicas.

No entanto, a participação dos estados na receita tributária global vem decrescendo vis-à-vis as duas outras esferas de governo. Apesar de os estados coletarem o maior imposto em termos absolutos - o ICMS -, em uma perspectiva histórica sua participação no bolo tributário nacional está diminuindo. Em 1960, a participação dos estados era de $34 \%$, caindo para $22 \%$ durante o regime militar. Nos anos iniciais da redemocratização, os estados conseguiram recuperar sua posição relativa, alcançando, em 1991, 29\%, do total dos recursos tributários. Após esse período, a participação dos estados na receita tributária total vem declinando, atingindo 25\% em 2003 (Afonso, 2004). Apesar desse relativo declínio, os estados continuam administrando parcela importante da receita e da despesa pública total, e, mais do que isso, são grandes devedores.

Os dados e os fatos mostram a importância dos governos estaduais no controle da receita, da despesa e do endividamento públicos, inclusive no médio e longo prazo. ${ }^{9}$ No entanto, a questão a ser discutida em relação à agenda macroeconômica é 
saber por que os políticos estaduais aceitaram as políticas restritivas de gasto formuladas pelo governo federal. Também importante é investigar em que itens de despesas incidiram os cortes, dado que com a renegociação de suas dívidas com o governo federal, parcela considerável dos recursos estaduais passou a ser canalizada para o pagamento da dívida.

\section{A politica federal de ajuste fiscal nos estados}

O endividamento dos estados nas últimas décadas teve início com a reforma tributária de 1966, aliada à política do regime militar de autorizar os estados a contraírem novas dívidas para o financiamento de dívidas anteriores, com o objetivo de manter o alto ritmo dos investimentos. Com a Constituição de 1988, a questão dos recursos estaduais foi parcialmente equacionada, tanto a dos estados economicamente mais desenvolvidos, pelo aumento da base do ICMS, como a dos menos desenvolvidos, pelo aumento das transferências federais para o FPE - Fundo de Participação dos Estados. No entanto, o equacionamento da dívida passada só ocorreu quando o Plano Real conseguiu controlar a inflação, permitindo ao governo federal adotar mecanismos para enfrentar o que era considerado um dos pilares da estabilização fiscal: o controle das contas públicas e do endividamento dos estados. Isso porque a dívida líquida de estados e municípios vinha aumentando ininterruptamente, de 5,8\% do PIB, em 1989, para 13\%, em 1997, impulsionada, inclusive, pela política de juros altos que sustentava o Plano Real. A participação dessa dívida na dívida total líquida do setor público, que era de 15\% em 1989, alcançou 42\% em 1997 (Rigoton e Giambiagi, 1998). ${ }^{10}$

A tarefa do governo federal não seria fácil, uma vez que entre 1988 e 1997 sete acordos foram firmados entre o governo federal e os estados para a renegociação de suas dívidas, os quais não foram cumpridos pelos estados. ${ }^{11} \mathrm{Com}$ a consolidação do Plano Real, o governo federal baixou várias medidas voltadas para a renegociação das dívidas estaduais, para a privatização ou extinção dos bancos comerciais estaduais e para a privatização de empresas estaduais de serviços públicos. ${ }^{12}$
Tais mudanças nas regras mostram que $\mathrm{O}$ Brasil optou, naquele momento, por dois tipos de mecanismos para controlar o endividamento dos governos subnacionais. De acordo com a classificação de Ter-Minassian e Craig (1997), existem quatro tipos de mecanismos para esse controle: disciplina de mercado, cooperação, controles baseados em regras e controle administrativo pelo governo central, sendo que no caso brasileiro a opção para enfrentar o fracasso das tentativas anteriores recaiu sobre os dois últimos mecanismos, que foram adotados de forma simultânea. Essas mudanças mostram que o Brasil evoluiu de uma política federal de controle fiscal tênue (soft budget constraints) para rígido (bard budget constraints). ${ }^{13}$

Com base nessas novas regras, a União assumiu, em valores de 1997, R \$ 95,4 bilhões de dívidas estaduais, sendo $\mathrm{R} \$ 71,3$ bilhões refinanciados pelo prazo máximo de trinta anos, a uma taxa de juros real mínima de $6 \%$ a.a.; $\mathrm{R} \$ 10,6$ bilhões a amortizar com receitas advindas das privatizações; e R\$ 13,5 bilhões referentes à diferença de encargos pela rolagem das dívidas entre a data de corte e a data de assinatura dos contratos. O montante assumido pela União equivalia a $11 \%$ do PIB e a $88,5 \%$ da dívida líquida de estados e municípios em dezembro de 1997. Em valores de 2001, a dívida assumida pela União foi de R\$ 132 bilhões.

Nos novos contratos firmados entre o governo federal e cada estado foram fixados limites máximos de comprometimento da Receita Líquida Real (RLR) com os encargos da dívida e proibiu-se a emissão de dívida nova enquanto a dívida financeira do estado fosse maior do que sua RLR anual. ${ }^{14} \mathrm{O}$ principal mecanismo de sanção pelo descumprimento dos contratos foi a vinculação dos repasses do FPE, que já constava de alguns contratos anteriores, e, em alguns casos, $\mathrm{O}$ bloqueio de receitas próprias estaduais. A renegociação foi comandada pela Secretaria do Tesouro Nacional (STN), que está autorizada a realizar visitas aos estados para a revisão das metas dos contratos. ${ }^{15}$

Após a assinatura dos acordos, a maioria dos estados, mas não todos, adotaram políticas fiscais rigorosas, constrangidos pelas novas regras, mas 
também por outras que as seguiram, tal como a promulgação, em 2000, da Lei de Responsabilidade Fiscal (LRF), que não só fixa limites para despesas com pessoal, como também proíbe o governo federal de assumir novas dívidas contraídas pelos estados. ${ }^{16}$ A LRF não só complementa e aprofunda as medidas anteriores, mas avança no controle dos gastos públicos porque, até sua promulgação, a maioria das medidas era voltada para a dívida, sem limitar despesas futuras. Nesse sentido, a LRF fecha o ciclo de restrições sobre as finanças públicas, notadamente dos estados. Além dessas medidas legais, a maioria dos recursos para investimentos e para programas sociais nos estados está hoje disponível apenas nos organismos multilaterais, e para ter acesso a esses recursos as contas têm que estar ajustadas. Os estados vêem recorrendo cada vez mais a esses empréstimos inclusive porque não são sujeitos aos limites de endividamento da LRF.

Como conseqüência dessas novas regras, os estados reduziram suas despesas em 2,1\% em termos reais no período entre 1999 e 2001 . As despesas com pessoal foram reduzidas em $2,2 \%$, e entre 2000 e 2004 , a redução foi de $3 \%$, passando de $\mathrm{R} \$$ 62,8 bilhões para R \$ 61,1 bilhões. Assim como ocorreu na esfera federal, a redução mais drástica ocorreu no item "despesas de capital". Em 1999, essas despesas respondiam por 19,5\% dos gastos totais estaduais, passando a 13,2\% em 2001. Apesar da redução nas despesas com pessoal, os gastos com o custeio da máquina pública estadual aumentaram em 5,6\% no período (Afonso, 2004, p. 17). Esses números mostram que, no conjunto, a capacidade de investimento dos estados foi profundamente reduzida pela reestruturação fiscal e que a despesa com pessoal foi reduzida em termos reais, embora não na mesma proporção dos investimentos.

\section{A dinâmica eleitoral estadual nos anos de 1990}

Das 27 entidades estaduais, doze conseguiram combinar ajuste fiscal com vitória eleitoral. A Tabela 1 mostra o resultado das eleições estaduais para governador em 1994 e 1998. A quase totalidade do refinanciamento das dívidas dos estados ocorreu entre 1997 e início de $1998,{ }^{17}$ o que faz com que o timing entre o início do ajuste fiscal e o da realização das eleições de 1998 possa ser considerado pequeno para que os eleitores sentissem algum impacto. No entanto, os recursos públicos estaduais foram reduzidos logo após a assinatura dos contratos devido à vinculação imediata de $13 \%$ da receita estadual ao pagamento mensal à União. Além do mais, em 1998, a receita total dos estados foi reduzida em relação ao ano anterior, passando de $\mathrm{R} \$ 239.282$ milhões em 1997 para R\$ 179.416 milhões em 1998 (Mora, 2002 , p. 35). Ou seja, de fato, a receita estadual total em 1998 foi menor do que no ano anterior, assim como a capacidade de despesa também foi limitada pelo início do pagamento da dívida.

\section{Ajuste fiscal e dinâmica eleitoral em estados selecionados}

Dos 12 estados que combinaram ajuste fiscal com vitória eleitoral, três foram selecionados para esta pesquisa: Bahia, Ceará e Paraná. Esses estados partilham várias características comuns: (a) dois abrigam populações/eleitores de tamanho semelhante; (b) os três conseguiram manter, na última década, suas posições relativas no PIB nacional, com o Paraná em $6^{\circ}$ lugar, a Bahia em $5^{\circ}$ e o Ceará em $13^{\circ}$, o que não foi conseguido por alguns estados que perderam suas posições relativas; (c) o montante de suas dívidas está próximo da média nacional; e (d) a relação entre o endividamento e a RLR, importante indicador fiscal, é semelhante. ${ }^{18}$ No entanto, as características socioeconômicas desses estados e dos seus eleitores são contrastantes, como se verá adiante.

A principal característica política comum é que nos três estados suas lideranças políticas conseguiram manter, até recentemente, grande controle sobre as instituições e os processos decisórios estaduais. No entanto, a forma como essas lideranças exercem controle sobre as instituições varia. A Bahia tem tido uma liderança centralizadora, autoritária e carismática, que se constituiu no regime militar e se consolidou no regime democrático; o Ceará vinha sendo governado por um grupo cuja base de sustentação original foi a 
Tabela 1

Resultados das Eleições de 1994 e 1998 para Governador, por Partido e Participação da Dívida dos Estados no PIB Estadual e na Receita Líquida Real (RLR)

\begin{tabular}{|c|c|c|c|c|}
\hline \multirow{2}{*}{ ESTADO } & \multicolumn{2}{|c|}{ PARTIDO } & \multirow{2}{*}{$\begin{array}{c}\text { DÍVIDA EM \% } \\
\text { DO PIB }\end{array}$} & \multirow{2}{*}{$\begin{array}{l}\text { Dívida EM \% } \\
\text { DA RLR }\end{array}$} \\
\hline & 1994 & 1998 & & \\
\hline Acre & PPR & PT & 31 & 1,3 \\
\hline Alagoas & PMDB & PSB & 38 & 3,1 \\
\hline Amazonas & PPR & PFL & 14 & 1,3 \\
\hline Amapá (*) & PSB & PSB & 7 & 0,2 \\
\hline Bahia (*) & PFL & PFL & 21 & 2,2 \\
\hline Ceará (*) & PSDB & PSDB & 21 & 1,4 \\
\hline Distrito Federal & PT & PMDB & 5 & 0,5 \\
\hline Espírito Santo & PT & PMDB & 17 & 1,6 \\
\hline Goiás & PMDB & PSDB & 43 & 4,4 \\
\hline Maranhão (*) & PFL & PFL & 41 & 3,1 \\
\hline Mato Grosso & PDT & PSDB & 40 & 3,1 \\
\hline Mato Grosso do Sul & PMDB & PT & 28 & 3,6 \\
\hline Minas Gerais & PSDB & PMDB & 26 & 3,3 \\
\hline Pará (*) & PSDB & PSDB & 8 & 1,0 \\
\hline Paraíba (*) & PMDB & PMDB & 30 & 2,1 \\
\hline Pernambuco & PSB & PMDB & 19 & 1,8 \\
\hline Piauí (*) & PMDB & PMDB & 43 & 2,3 \\
\hline Paraná $(*)$ & PDT & PDT & 15 & 1,8 \\
\hline Rio de Janeiro & PSDB & PDT & 23 & 3,7 \\
\hline Rio Grande do Norte $\left(^{*}\right)$ & PMDB & PMDB & 13 & 1,1 \\
\hline Rondônia & PMDB & PFL & 19 & 2,1 \\
\hline Roraima & PTB & PPB & 25 & 1,0 \\
\hline Rio Grande do Sul & PMDB & PT & 25 & 3,1 \\
\hline Santa Catarina & PMDB & PPB & 21 & 2,6 \\
\hline Sergipe $\left(^{*}\right)$ & PSDB & PSDB & 24 & 1,4 \\
\hline São Paulo (*) & PSDB & PSDB & 19 & 2,9 \\
\hline Tocantins $(*)$ & PPR & PFL & 26 & 0,6 \\
\hline Média nacional & & & 21 & 2,6 \\
\hline
\end{tabular}

(*) Reeleição do(a) governador(a) ou de candidato(a) por ele (ela) apoiado.

Fontes: Site www.tse.gov.br e Mora (2002, pp. 55-56).

insatisfação de um segmento da elite empresarial com a forma de gerir o estado dos velhos coronéis; o Paraná caracterizou-se naquele período por um arranjo político mais baseado na imagem de gestões ditas tecnocráticas, com a incorporação de quadros da tecnocracia atuante durante o regime militar e de quadros oriundos do setor privado. O Paraná e a Bahia foram governados no período do ajuste fiscal pelo PFL, e o Ceará, pelo PSDB, partidos da coalizão federal construída em 1994.
Os três estados também adotaram com rigor a política nacional de ajuste fiscal, tendo sido pioneiros na renegociação de suas dívidas com a União, além de se empenharem em privatizações diversas, inclusive de seus bancos comerciais ainda em 1998, e na reforma do sistema previdenciário estadual.

Se os três estados apresentam várias características políticas comuns e adotaram rotas de ajuste fiscal semelhantes, suas características socioeconômicas são distintas, posicionando, de um lado, os dois estados do Nordeste e, de outro, o Paraná, 
Tabela 2

Indicadores Socioeconômicos e Territoriais dos Estados Selecionados

\begin{tabular}{|c|c|c|c|c|c|c|c|c|}
\hline ESTADO & População & $\begin{array}{c}\mathrm{N}^{\circ} \\
\text { MuniCíPIOS }\end{array}$ & $\begin{array}{c}\text { PIB } \\
\mathrm{R} \$ \text { MILHÃO }\end{array}$ & $\begin{array}{c}\text { PIB } \\
\text { NO RANKING } \\
\text { NACIONAL }\end{array}$ & $\begin{array}{c}\text { PIB } \\
\text { PER CAPITA } \\
\mathrm{R} \$\end{array}$ & $\begin{array}{c}\text { PIB } \\
\text { PER CAPITA } \\
\text { NO RANKING } \\
\text { NACIONAL }\end{array}$ & \begin{tabular}{|c|}
$\%$ DA \\
POPULAÇÃO \\
SEM $1^{\circ}$ \\
GRAU COM- \\
PLETO \\
\end{tabular} & $\begin{array}{c}\text { TAXA DE } \\
\text { MORTALIDADE } \\
\text { INFANTIL }\end{array}$ \\
\hline BAHIA & 13.066 .910 & 417 & 62.103 & $6^{\mathrm{O}}$ & 4.629 & $15^{\mathrm{O}}$ & 46,7 & 45,4 \\
\hline Ceará & 7.418 .478 & 184 & 24.204 & $13^{\mathrm{O}}$ & 3.129 & $21^{\mathrm{O}}$ & 44,3 & 52,4 \\
\hline PARANÁ & 9.558 .454 & 399 & 81.449 & $5^{\mathrm{O}}$ & 8.241 & $7^{\mathrm{O}}$ & 26,8 & 24,3 \\
\hline
\end{tabular}

Fonte: Site http://www.ibge.br/ibge/estatística/contasregionais.

Tabela 3

BA, CE e PR - Nível de Endividamento - 1999 (em R\$ milhões)

\begin{tabular}{|c|c|c|c|c|c|}
\hline Estado & $\begin{array}{c}\text { Endividamento } \\
\text { TOtal }\end{array}$ & $\begin{array}{c}\text { Receita Líquida } \\
\text { Real }\end{array}$ & PIB & $\begin{array}{c}\text { Endividamento/ } \\
\text { PIB (\%) }\end{array}$ & $\begin{array}{c}\text { Endividamento/ } \\
\text { Receita Líquida } \\
\text { ReAL }\end{array}$ \\
\hline BAHIA & 9.100 & 4.161 & 44.250 & 21 & 2,2 \\
\hline CEARÁ & 4.128 & 2.919 & 19.547 & 21 & 1,4 \\
\hline PARANÁ & 9.533 & 5.250 & 62.810 & 15 & 1,8 \\
\hline
\end{tabular}

Fonte: Adaptado de Mora (2002: 55, 56).

Tabela 4

BA, CE, PR -Renegociação das Dívidas - dez. 2000 (em R\$ mil)

\begin{tabular}{|c|c|c|c|c|c|c|c|c|}
\hline Estado & \begin{tabular}{|c} 
DATA DE \\
ASSINATURA \\
DO \\
CONTRATO
\end{tabular} & $\begin{array}{c}\text { DÍVIDA } \\
\text { ASSUMIDA } \\
\text { PELA } \\
\text { UNIÃO }\end{array}$ & $\begin{array}{c}\text { DÍVIDA } \\
\text { REFINANCIA- } \\
\text { DA PELA } \\
\text { UNIÃO }\end{array}$ & $\begin{array}{l}\text { SUBSíDIO } \\
\text { CONCEDIDO }\end{array}$ & $\begin{array}{l}\text { PRAZO } \\
\text { (ANOS) }\end{array}$ & $\begin{array}{l}\text { LIMITE DE } \\
\text { COMPROME- } \\
\text { TIMENTO } \\
(\%)\end{array}$ & $\begin{array}{l}\text { ENCARGOS } \\
(\% \text { A .A .) }\end{array}$ & $\begin{array}{c}\text { PARTICIPAÇÃO \% NO } \\
\text { TOTAL DA DÍVIDA } \\
\text { DOS ESTADOS }\end{array}$ \\
\hline BAHIA & 01.12 .97 & 1.048 .995 & 1.211 .391 & 82.049 & 30 & 11,5 a 13 & IGP-DI+6.0 & 0,9 \\
\hline CEará & 17.10 .97 & 153.051 & 172.360 & 15.163 & 15 & 12 & IGP-DI+6.0 & 0,1 \\
\hline Paraná & 31.03 .98 & 568.114 & 614.446 & 76.557 & 30 & 12 a 13 & IGP-DI+6.0 & 0,5 \\
\hline
\end{tabular}

Fonte: Adaptado de Mora (2002, pp. 24, 27).

principalmente no que se refere aos indicadores sociais. A Tabela 2 sintetiza os principais indicadores dos três estados.

Como referido, os três estados selecionados são considerados os que mais se adaptaram às políticas federais de ajuste fiscal, sendo que a Bahia e o Ceará são constantemente citados pelo
Banco Mundial como exemplos de ajustes fiscais bem-sucedidos. As Tabelas 3 e 4 mostram a posição da Bahia, do Ceará e do Paraná em relação ao endividamento e às renegociações de suas dívidas com o governo federal.

Outro componente do ajuste fiscal dos estados foi a redução dos gastos estaduais com pessoal. A 
Tabela 5

BA, CE e PR - Evolução das Despesas de Pessoal - 1995-2000

\begin{tabular}{|c|c|c|c|c|c|c|c|c|c|c|c|c|}
\hline EstAdo & \multicolumn{4}{|c|}{ EM R\$ MILHÕES DE DEZEMBRo/2000 } & \multicolumn{5}{c|}{ EM PERCENTUAL DA RLR } \\
\hline & 1995 & 1996 & 1997 & 1998 & 1999 & 2000 & 1995 & 1996 & 1997 & 1998 & 1999 & 2000 \\
\hline CEARÁ & 1.021 & 1.046 & 1.317 & 1.271 & 1.561 & 1.585 & 35 & 38 & 51 & 43 & 47 & 52 \\
\hline BAHIA & 2.533 & 2.647 & 3.136 & 3.080 & 2.863 & 2.348 & 55 & 54 & 50 & 51 & 52 & 45 \\
\hline PARANÁ & 3.399 & 3.757 & 3.912 & 3.968 & 3.602 & 3.131 & 65 & 68 & 67 & 62 & 57 & 46 \\
\hline BRASIL & 60.988 & 67.034 & 64.615 & 71.926 & 73.553 & 70.754 & 62 & 65 & 60 & 62 & 63 & 58 \\
\hline
\end{tabular}

Fonte: Adaptado de Mora (2002, pp. 39-40).

Tabela 6

BA, CE e PR - Resultado das Eleições de 1994 para Governador

\begin{tabular}{|c|c|c|c|c|}
\hline ESTADO & CANDIDATOS & PARTIDO & $\begin{array}{l}\text { VOTAÇÃO (N }{ }^{0} \\
\text { ABSOLUTOS) }\end{array}$ & VOTAÇÃO (\%) \\
\hline BAHIA ( $1^{\circ}$ turno $)$ & $\begin{array}{l}\text { Paulo Souto } \\
\text { João Durval } \\
\text { Outros } \\
\text { Brancos/Nulos } \\
\text { Abstenções }\end{array}$ & $\begin{array}{l}\text { PFL } \\
\text { PMN } \\
\text { PSDB, PMDB e PRN }\end{array}$ & $\begin{array}{l}1.617 .127 \\
829.646 \\
779.239\end{array}$ & $\begin{array}{l}49,30 \\
25,29 \\
25,40 \\
36,38 \\
26,67\end{array}$ \\
\hline BAHIA ( $2^{\circ}$ turno) & $\begin{array}{l}\text { Paulo Souto } \\
\text { João Durval } \\
\text { Brancos/Nulos } \\
\text { Abstenções }\end{array}$ & $\begin{array}{l}\text { PFL } \\
\text { PMN }\end{array}$ & $\begin{array}{l}2.235 .659 \\
1.577 .043\end{array}$ & $\begin{array}{l}58,64 \\
41,36 \\
12,71 \\
37,88\end{array}$ \\
\hline Ceará ( $1^{\circ}$ turno $)$ & $\begin{array}{l}\text { Tasso Jereissati } \\
\text { Juraci Magalhães } \\
\text { Outros } \\
\text { Brancos/Nulos } \\
\text { Abstenções }\end{array}$ & $\begin{array}{l}\text { PSDB } \\
\text { PMDB } \\
\text { PT/PSTU/PRONA }\end{array}$ & $\begin{array}{l}1.368 .757 \\
930.407 \\
174.967\end{array}$ & $\begin{array}{c}55,32 \\
37,61 \\
7,07 \\
20,83 \\
22,01\end{array}$ \\
\hline PARANÁ $\left(1^{\circ}\right.$ turno $)$ & $\begin{array}{l}\text { Jaime Lerner } \\
\text { Álvaro Dias } \\
\text { Outros } \\
\text { Brancos/Nulos } \\
\text { Abstenções }\end{array}$ & $\begin{array}{l}\mathrm{PDT}\left(^{*}\right) \\
\mathrm{PP} \\
\mathrm{PT} / \mathrm{PRN} / \mathrm{PRONA} / \mathrm{PL} / \mathrm{PSD}\end{array}$ & $\begin{array}{c}2.070 .970 \\
1.455 .648 \\
249.211\end{array}$ & $\begin{array}{c}54,85 \\
38,55 \\
6,6 \\
20,41 \\
17,45\end{array}$ \\
\hline
\end{tabular}

Fonte: Tribunal Superior Eleitoral (http://www.tse.gov.br).

(*) Lerner concorreu pelo PDT e no decorrer do mandato filiou-se ao PFL.

Tabela 5 apresenta a evolução da despesa com pessoal nos três estados, mostrando que a Bahia reduziu consideravelmente essa despesa e que o Paraná a reduziu principalmente em relação a RLR. No Ceará, ocorreu decréscimo entre 1997 e 1998, havendo a despesa com pessoal voltado a crescer a partir de 1999, embora abaixo da média nacional e do limite de 60\% fixado pela LRF. Ressalte-se, ainda, que a redução dessa despesa foi realizada pelos três estados antes mesmo do teto imposto pela LRF. Despesas com pessoal devem ser destacadas por estar relacionada com um dos principais argumentos dos que vêm na política estadual o território exclusivo de práticas clientelistas, as quais se manifestam, segundo essa lógica, na concessão de empregos públicos ou nas promessas de concedê-los. 
Tabela 7

BA, CE e PR - Resultado das Eleições de 1998 para Governador

\begin{tabular}{|c|c|c|c|c|}
\hline ESTADO & CANDIDATOS & PARTIDO & $\begin{array}{l}\text { VOTAÇÃO (No } \\
\text { ABSOLUTOS) }\end{array}$ & VOTAÇÃO (\%) \\
\hline BAHIA ( $1^{\circ}$ turno) & $\begin{array}{l}\text { Cesar Borges } \\
\text { José Ribeiro } \\
\text { Outros } \\
\text { Brancos/Nulos } \\
\text { Abstenções }\end{array}$ & $\begin{array}{l}\text { PFL } \\
\text { PT } \\
\text { PDT/PRONA }\end{array}$ & $\begin{array}{r}2.418 .765 \\
524.796 \\
516.297\end{array}$ & $\begin{array}{l}69,91 \\
15,71 \\
14,93 \\
36,00 \\
31,84\end{array}$ \\
\hline CEARÁ (1º turno) & $\begin{array}{l}\text { Tasso Jereissati } \\
\text { Luiz Gonzaga Mota } \\
\text { Outros } \\
\text { Brancos/Nulos } \\
\text { Abstenções }\end{array}$ & $\begin{array}{l}\text { PSDB } \\
\text { PMDB } \\
\text { PT/PMN/PSTU }\end{array}$ & $\begin{array}{r}1.569 .110 \\
548.509 \\
384.214\end{array}$ & $\begin{array}{l}55,32 \\
21,92 \\
15,36 \\
24,21 \\
23,27\end{array}$ \\
\hline PARANÁ $\left(1^{\circ}\right.$ turno $)$ & $\begin{array}{l}\text { Jaime Lerner } \\
\text { Roberto Requião } \\
\text { Outros } \\
\text { Brancos/Nulos } \\
\text { Abstenções }\end{array}$ & $\begin{array}{l}\text { PFL } \\
\text { PMDB } \\
\text { PRONA/PSTU }\end{array}$ & $\begin{array}{r}2.031 .241 \\
1.786 .115 \\
72.976\end{array}$ & $\begin{array}{c}52,21 \\
45,91 \\
1,88 \\
22,74 \\
21,12\end{array}$ \\
\hline
\end{tabular}

Fonte: Tribunal Superior Eleitoral (http://www.tse.gov.br).

Apesar de suas várias similaridades e de suas diferenças socioeconômicas, os três estados adotaram políticas de ajuste fiscal semelhantes em timing, conteúdo e profundidade. ${ }^{19}$ A decisão desses estados de adotarem políticas restritivas de gasto contradiz as hipóteses sobre o funcionamento da política estadual, que seria baseado, como já mencionado, em apenas uma lógica (clientelismo e política tradicional). Dessa hipótese, pode-se inferir que políticas de ajuste fiscal trariam, no mínimo, alterações na formação de coalizões eleitorais para o Executivo estadual. Isso porque, com o ajuste, segmentos do eleitorado que dependem de recursos públicos para interesses particularistas (ou para a provisão de bens privados) seriam prejudicados. No caso dos estados brasileiros, argumentam os brasilianistas, esse segmento estaria concentrado no Nordeste e nos municípios mais pobres do interior do Brasil. Como, então, foi possível conciliar ajuste fiscal e vitória eleitoral, já que nos estados aqui analisados os governadores que adotaram o cardápio completo do ajuste fiscal foram reeleitos (Ceará e Paraná) ou elegeram seus sucessores (Bahia), em especial os dois do Nordeste?

Assim como ocorre com as características semelhantes de ajuste fiscal, os resultados eleitorais nos três estados apresentam mais semelhanças do que diferenças. As Tabelas 6 e 7 mostram os resultados dos pleitos para governador nas eleições de 1994 - antes do ajuste fiscal - e nas de 1988 - após o ajuste fiscal.

Em 1994, a Bahia foi o único dos três estados onde ocorreu $2^{\circ}$ turno para o cargo de governador. Naquela eleição, o candidato da coalizão liderada por Antônio Carlos Magalhães (ACM) concorreu contra um candidato de um partido fraco na Bahia, que havia sido governador na gestão 1983-1987, com o apoio do grupo de ACM, mas deixou o cargo com baixos índices de aprovação popular e rompido com o grupo que o apoiou. Esses resultados eleitorais, que serão desagregados adiante por município, mostram que o eleitorado da Bahia, embora tenha dado a vitória ao grupo de ACM, que estava ocupando o cargo de governador, não o fez no mesmo grau que os eleitores do Ceará e 
Tabela 7

BA, CE e PR - Resultado das Eleições de 1998 para Governador

\begin{tabular}{|c|c|c|c|c|}
\hline ESTADO & CANDIDATOS & PARTIDO & $\begin{array}{l}\text { VOTAÇÃO (N }{ }^{\circ} \\
\text { ABSOLUTOS) }\end{array}$ & VOTAÇÃO (\%) \\
\hline BAHIA (1º turno) & $\begin{array}{l}\text { Cesar Borges } \\
\text { José Ribeiro } \\
\text { Outros } \\
\text { Brancos/Nulos } \\
\text { Abstenções }\end{array}$ & $\begin{array}{l}\text { PFL } \\
\text { PT } \\
\text { PDT/PRONA }\end{array}$ & $\begin{array}{r}2.418 .765 \\
524.796 \\
516.297\end{array}$ & $\begin{array}{l}69,91 \\
15,71 \\
14,93 \\
36,00 \\
31,84\end{array}$ \\
\hline CEARÁ ( $1^{\circ}$ turno $)$ & $\begin{array}{l}\text { Tasso Jereissati } \\
\text { Luiz Gonzaga Mota } \\
\text { Outros } \\
\text { Brancos/Nulos } \\
\text { Abstenções }\end{array}$ & $\begin{array}{l}\text { PSDB } \\
\text { PMDB } \\
\text { PT/PMN/PSTU }\end{array}$ & $\begin{array}{r}1.569 .110 \\
548.509 \\
384.214\end{array}$ & $\begin{array}{l}55,32 \\
21,92 \\
15,36 \\
24,21 \\
23,27\end{array}$ \\
\hline PARANá $\left(1^{\circ}\right.$ turno $)$ & $\begin{array}{l}\text { Jaime Lerner } \\
\text { Roberto Requião } \\
\text { Outros } \\
\text { Brancos/Nulos } \\
\text { Abstenções }\end{array}$ & $\begin{array}{l}\text { PFL } \\
\text { PMDB } \\
\text { PRONA/PSTU }\end{array}$ & $\begin{array}{r}2.031 .241 \\
1.786 .115 \\
72.976\end{array}$ & $\begin{array}{c}52,21 \\
45,91 \\
1,88 \\
22,74 \\
21,12\end{array}$ \\
\hline
\end{tabular}

Fonte: Tribunal Superior Eleitoral (http://www.tse.gov.br).

do Paraná, já que nesses dois estados seus governadores venceram as eleições ainda no $1^{\circ}$ turno. Tasso Jereissati manteve a adesão do eleitorado ao seu partido, pois sucedeu a Ciro Gomes, que integrava seu grupo político. Jaime Lerner, no entanto, chegava ao governo do estado em oposição ao grupo que estava no controle do governo estadual, impulsionado por várias administrações avaliadas como bem-sucedidas na prefeitura de Curitiba.

Em 1998, após a implantação do ajuste fiscal, já não existem diferenças nos resultados eleitorais. Os candidatos governistas que haviam implantado o ajuste fiscal ganharam no $1^{\circ}$ turno, sendo que na Bahia e no Ceará a margem de diferença entre o primeiro e o segundo colocados foi significativa. Os candidatos vitoriosos nos três estados usaram o ajuste fiscal em curso e implementado por seus partidos como um dos pontos principais de suas campanhas e compromissos eleitorais.

Os resultados das eleições de 2002 para governador são apresentados a seguir. Os dados não são objeto de tratamento desagregado como os das duas outras eleições, já que a questão central da pesquisa se refere ao ajuste fiscal, que foi mantido nos três estados, inclusive com a sustentação de superávits primários. Nota-se, no entanto, um quadro eleitoral distinto do de 1994 e, principalmente, do de 1998. No Paraná e no Ceará ocorreu $2^{\circ}$ turno, e as disputas entre os candidatos nos três estados foi mais competitiva. Mesmo na Bahia, onde não houve $2^{\circ}$ turno, os votos dados ao candidato derrotado foram maiores do que em 1994 e, principalmente, do que em 1998. No Paraná, o partido de Lerner, o PFL, não teve candidato próprio, apoiando o candidato do PSDB, que não chegou ao $2^{\circ}$ turno. Na Bahia e no Ceará, embora seus líderes tenham mantido o controle dos governos estaduais, as eleições de 2002 mostraram que o eleitorado já não lhes dava o apoio maciço das eleições anteriores, sinalizando as derrotas que sofreriam nas eleições de 2006. ${ }^{20}$ No entanto, tais mudanças não podem ser avaliadas como um sinal de rejeição à política de ajuste fiscal, dado que, em 2002, dois estados continuaram sendo governados pelo mesmo grupo político e os candidatos vencedores nos três estados não concorreram com uma plata- 
Tabela 8

BA, CE e PR - Resultado das Eleições de 2002 para Governador

\begin{tabular}{|c|c|c|c|c|}
\hline ESTADO & CANDIDATOS & PARTIDO & $\begin{array}{l}\text { VOTAÇÃO (No } \\
\text { ABSOLUTOS) }\end{array}$ & (\%) VOTOS VÁLIDOS \\
\hline BAHIA & $\begin{array}{l}\text { Paulo G. Souto } \\
\text { Jacques Wagner } \\
\text { Outros }\end{array}$ & $\begin{array}{l}\text { PFL } \\
\text { PT } \\
\text { PAN/PTC/PMDB/PSB/PSTU/PCO }\end{array}$ & $\begin{array}{l}2.871 .025 \\
2.057 .022 \\
418.895\end{array}$ & $\begin{array}{l}53,69 \\
38,47 \\
7,84\end{array}$ \\
\hline CEARÁ ( $1^{\circ}$ turno $)$ & $\begin{array}{l}\text { Lúcio Alcântara } \\
\text { José Airton }\end{array}$ & $\begin{array}{l}\text { PSDB } \\
\text { PT }\end{array}$ & $\begin{array}{l}1.625 .202 \\
924.690\end{array}$ & $\begin{array}{l}50,04 \\
40,96\end{array}$ \\
\hline Paraná ( $1^{\circ}$ turno) & $\begin{array}{l}\text { Roberto Requião } \\
\text { Álvaro Dias }\end{array}$ & $\begin{array}{l}\text { PMDB } \\
\text { PDT }\end{array}$ & $\begin{array}{l}2.681 .811 \\
2.180 .922\end{array}$ & $\begin{array}{l}55,15 \\
44,85\end{array}$ \\
\hline
\end{tabular}

Fonte: Tribunal Superior Eleitoral (http://www.tse.gov.br)

forma antiajuste, embora Requião, que governou o Paraná entre 1990 e 1994, mas que foi derrotado por Lerner em 1998, tivesse prometido rever algumas privatizações. Os governadores eleitos em 2002 continuaram mantendo a política restritiva de gasto, assim como os eleitos em 2006 não tinham nas suas plataformas eleitorais propostas antiajuste. ${ }^{21}$

Em suma, o comportamento dos eleitores em 1998 mostra que, no geral, a política de ajuste fiscal não teve impacto sobre os resultados eleitorais nesses três estados, uma vez que as coalizões políticas estaduais que adotaram o ajuste fiscal não foram afetadas do ponto de vista eleitoral. Como isso se explica diante do que nos diz grande parte da literatura? Ou seja, se políticas de ajuste fiscal restringem os gastos públicos e se a política estadual é, como afirmam muitos, movida pelo clientelismo e pela política tradicional, os quais se apóiam no uso dos recursos públicos, por que o eleitorado manteve no governo as coalizões políticas que reduziram seu acesso aos recursos públicos e por que os governadores arriscaram mudar o que a "escola clientelista" afirma ser sua principal fonte de sustentação eleitoral?

\section{Debatendo algumas hipóteses}

\section{A adesão dos estados ao ajuste fiscal}

Algumas análises mostram que o comportamento dos estados diante do ajuste fiscal não foi uniforme, apesar de os incentivos montados pelo governo federal terem sido semelhantes (Blanco, s.d). A literatura sobre os incentivos e os constrangimentos para a adoção de políticas de ajuste fiscal (Gibson, 1997; Lora, 2000; Remmer, 1993) levanta hipóteses que se aplicam mais à esfera central e não explicam as diferentes respostas dadas pelos estados em países federais. Para o caso brasileiro, foram também formuladas hipóteses mais gerais, tais como: (a) os estados aderiram às reformas devido à restauração da tradição brasileira de presidência forte, e o aprofundamento da crise de endividamento dos estados fez com que seus dirigentes optassem por políticas mais restritivas como uma solução do tipo second best (Kugelmas, 2001); (b) o sucesso do governo no controle da inflação deu ao presidente Fernando Henrique Cardoso condições para negociar com o Congresso e com os governadores a aprovação de reformas macroeconômicas (Samuels e Mainwaring, 2004) e de políticas sociais (Melo, 2005) que afetavam os interesses dos atores subnacionais; e (c) as preferências das elites dirigentes estaduais são influenciadas não apenas pelas instituições e por políticas federais, mas também por novas idéias, isto é, assim como o keynesianismo dominou a política econômica do pós-guerra, o ajuste fiscal dominou corações e mentes a partir dos anos de 1980, em especial em países com longas e recorrentes trajetórias inflacionárias (Souza, 2001).

É preciso ressaltar, todavia, que as políticas de ajuste praticadas pelos estados não foram vo- 
luntárias nem, obviamente, produto exclusivo da decisão das coalizões eleitorais que as implantaram, mas que os governadores que tomaram posse em 1995 e que seriam submetidos à nova disputa eleitoral em 1998, ano em que a maioria assinou acordos de renegociação de suas dívidas vinculando, em média, 13\% da Receita Líquida Corrente ao seu pagamento, correram o risco político-eleitoral de cumprir os acordos e de reduzir despesas, em um contexto em que as receitas estaduais, altamente concentradas no consumo, também declinavam devido ao baixo crescimento econômico do país. ${ }^{22}$

As hipóteses sobre as motivações dos governadores em relação à política de ajuste baseiam-se no que acontece nos estados como um todo. Existem diferenças não só no tipo de ajuste requerido em cada estado em função do perfil da dívida e da despesa, mas também no compromisso mais ou menos severo com o cumprimento de todas as medidas referentes ao ajuste. Precisamos entender, portanto, as diferentes performances dos governos estaduais em relação ao ajuste fiscal e, principalmente, por que alguns governadores adotaram o ajuste fiscal e continuaram vitoriosos eleitoralmente. Assim, algumas hipóteses mais específicas devem ser testadas, principalmente aquelas que incorporem o impacto territorial de uma política de ajuste fiscal nos resultados eleitorais das coalizões políticas que a implantou.

\section{A dinâmica político-eleitoral interna nos estados}

Se o papel dos governos estaduais no ajuste fiscal é mais conhecido, e se as hipóteses sobre por que os estados adotam ou não políticas de ajuste fiscal podem ser mais facilmente construídas, o mesmo não ocorre em relação à sustentação eleitoral de políticas que mudam o status quo.

$\mathrm{Na}$ ótica da agenda político-eleitoral, a questão a ser respondida refere-se à repercussão eleitoral do ajuste fiscal no território estadual, ou seja, se o ajuste afetou a base territorial de apoio do governador que o implantou. Como mencionado, não se busca investigar o papel desempenhado pela política de ajuste fiscal nas preferências dos eleitores, mas sim identificar a existência ou não de mudanças nos resultados eleitorais do ponto de vista territorial, tomando o território como unidade de análise e não o eleitor individualmente. Assim, o foco da investigação é saber se ocorreram ou não mudanças territoriais do ponto de vista dos votos dos eleitores a partir do ajuste fiscal, ou seja, analisar a dinâmica eleitoral interna (intra-estado) das restrições fiscais.

Para responder essa questão, torna-se necessário gerar hipóteses mais específicas que conciliem respostas sobre o que motivou algumas coalizões políticas estaduais a adotar políticas de ajuste fiscal e como tal opção se tornou eleitoralmente viável. Ou seja, é preciso entender melhor o cálculo feito pelos governadores quando optaram por políticas fiscais restritivas e as condições políticas e institucionais facilitadoras da sua adoção.

Hipóteses sobre o poder dos governadores já foram sugeridas por vários autores (Abrucio, 1998; Ames, 2001; Mainwaring, 1999, por exemplo). Algumas estão sendo testadas, outras perderam poder explicativo diante das mudanças ocorridas na década de 1990 e outras, ainda, precisam ser testadas. Uma vertente mais próxima desta pesquisa investiga a relação entre Legislativos estaduais e política de gasto público, com o objetivo de entender as diferenças entre os estados. Desposato (2001) analisou as preferências relativas dos eleitores, se por alocação de recursos na produção de bens públicos ou privados, sugerindo que existem fortes influências societárias no comportamento dos legisladores estaduais. Nos estados onde prevalece a preferência dos eleitores por bens privados, os partidos políticos são fracos e subservientes ao Executivo. Onde os cidadãos expressam preferências por bens públicos, os legisladores organizam-se mais em torno dos partidos e buscam maior independência do Executivo. Nos estados estudados, a Bahia aparece como um sistema quase puro de política baseada em bens privados (Paraná e Ceará não foram estudados por Desposato). A partir de sua análise, e considerando que políticas fiscais são bens públicos, dois pontos sobressaem: de um lado, as características políticas da Bahia descritas por Dantas (2003), Desposato (2001), Oliveira (2000) e Souza (1997) facilitariam a adoção, pelo governador, de política fiscal restritiva de gasto devido à submissão do Legislativo estadual ao Executivo. No entanto, se o que prevalece na Bahia é a preferência por bens privados, por que se fez o ajuste fiscal e como o mesmo foi sustentado 
eleitoralmente diante das preferências dos eleitores por bens privados?

Outro trabalho nesse mesmo veio foi realizado por Schneider (2001), que analisou as diferenças entre os estados em relação ao orçamento. Esse autor conclui que nos estados onde a competição eleitoral é menos acirrada (Bahia e Paraná; o Ceará não integra a amostra), os governadores puderam manter o orçamento relativamente fechado às pressões dos legisladores, em oposição àqueles onde a competição é mais exacerbada (Rio Grande do Sul e Pernambuco), tornando o orçamento mais aberto às demandas dos parlamentares, inclusive os de oposição.

Essas pesquisas aprofundam nosso conhecimento sobre o papel dos governadores na esfera estadual e sobre seu maior ou menor controle sobre as instituições políticas estaduais. No entanto, é preciso avançar para além da identificação sobre se os governadores têm ou não poder sobre as instituições políticas estaduais (formais ou informais) - e nos três casos estudados existe consenso de que esses governadores detinham grande controle sobre as instituições estaduais, inclusive contando com folgada maioria no Legislativo -, mas sim se as políticas restritivas de gasto tiveram impacto territorial nas eleições de 1998.

As hipóteses deste trabalho apóiam-se, parcialmente, em Gibson (1997), embora as conclusões não guardem total semelhança. Gibson analisou a tensão entre políticas macroeconômicas pró-mercado versus vitórias eleitorais na Argentina e no México, países que introduziram reformas macroeconômicas via partidos políticos de base populista. Ao analisar as repercussões dessas reformas nos resultados eleitorais e como foram montadas as coalizões eleitorais de apoio a essa política, Gibson discute as estratégias construídas pelos dois partidos para refazer suas históricas coalizões eleitorais, sugerindo que as políticas pró-mercado foram possíveis pelos rearranjos nos atores e nos papéis de duas subcoalizões: a metropolitana e a periférica. Da convivência dessas duas coalizões resultou uma aliança entre tecnocratas internacionalizados (subcoalizão metropolitana) e políticos paroquiais (subcoalizão periférica), que viabilizou as sucessivas vitórias eleitorais desses partidos, assim como as reformas pró-mercado. Gibson sugere ainda que a formação de coalizões políticas é fortemente in- fluenciada pela intercessão entre formulação de políticas públicas e política eleitoral. Ou seja, é necessário articular coalizões entre uma dada política pública e sua viabilidade eleitoral. A coalizão metropolitana incorporou novos atores ao processo político e deu novo ímpeto à reorganização da economia política nacional. A coalizão periférica ampliou o espaço territorial de poder do populismo e teve o papel de viabilizar maiorias eleitorais. Pode-se concluir, então, que a coalizão metropolitana seria uma coalizão em torno de políticas públicas, e a periférica, uma coalizão em torno de votos. ${ }^{23}$

A partir das conclusões de Gibson e da discussão a seguir, pode-se concluir que, com o retorno das eleições diretas para o Executivo estadual, as coalizões político-eleitorais de alguns estados conseguiram conciliar ajuste fiscal com vitórias eleitorais, o que aponta para a convivência de lógicas aparentemente antagônicas, mas que se complementam e se auto-sustentam. Daí porque foi possível a alguns governadores adotar políticas fiscais restritivas, mas ainda se manter viáveis eleitoralmente, combinando votos dos eleitores de municípios mais urbanizados, com maiores receitas orçamentárias per capita e melhores níveis de IDH, com os votos dos eleitores de territórios onde as condições de vida e de sobrevivência são mais precárias.

\section{Viabilidade eleitoral da politica de ajuste fiscal}

Esta seção desagrega os resultados eleitorais para governador em 1994 - antes do ajuste fiscal e em 1998 - após o ajuste fiscal. Para tanto, foram realizados os procedimentos que se seguem.

Primeiramente, os resultados eleitorais são plotados em mapas, permitindo melhor visualizar a distribuição territorial dos votos. ${ }^{24}$ Nos municípios em cinza, o candidato vencedor atingiu a maioria dos votos e em branco a maioria dos votos foi para os candidatos derrotados (Figura 1).

Os mapas confirmam que os governadores que optaram por políticas restritivas de gasto mantiveram ou aumentaram o apoio dos seus eleitores, assim como mostram a inexistência de mudanças territoriais significativas. Esses governadores foram capazes de manter suas bases tanto na subcoalizão 
Figura 1

Bahia, Ceará e Paraná (Resultados Eleitorais por município) 1994 e 1998

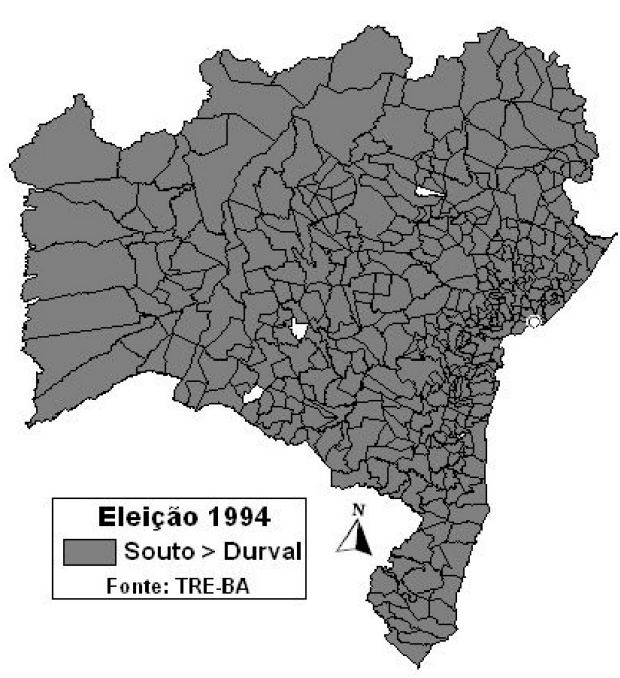

BAHIA

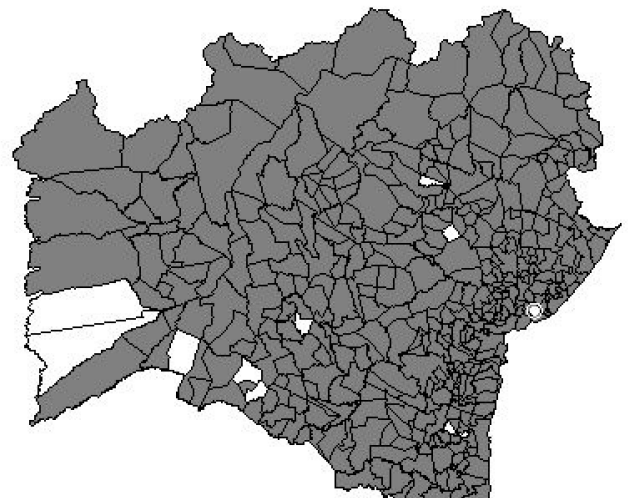

Eleição 1998

^

Fonte: TRE-BA

CEARÁ

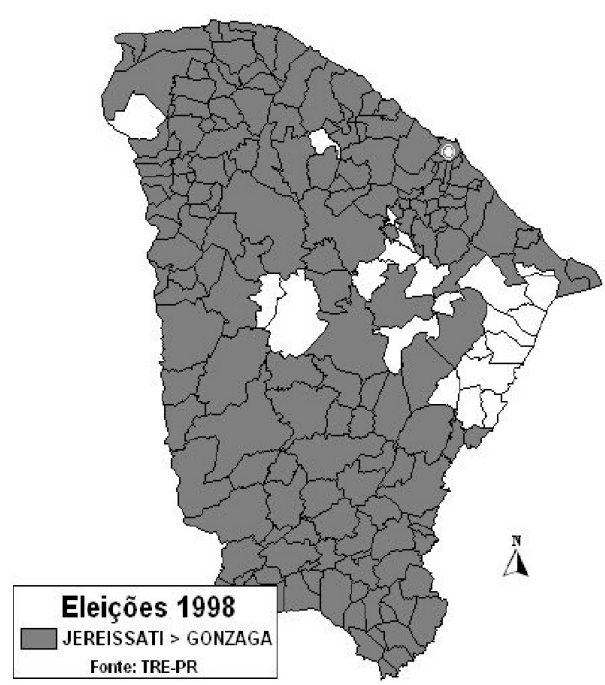

Eleições 1994

Fonte: TRE-PR
FISSATI > MA

Fonte: IRE-PR
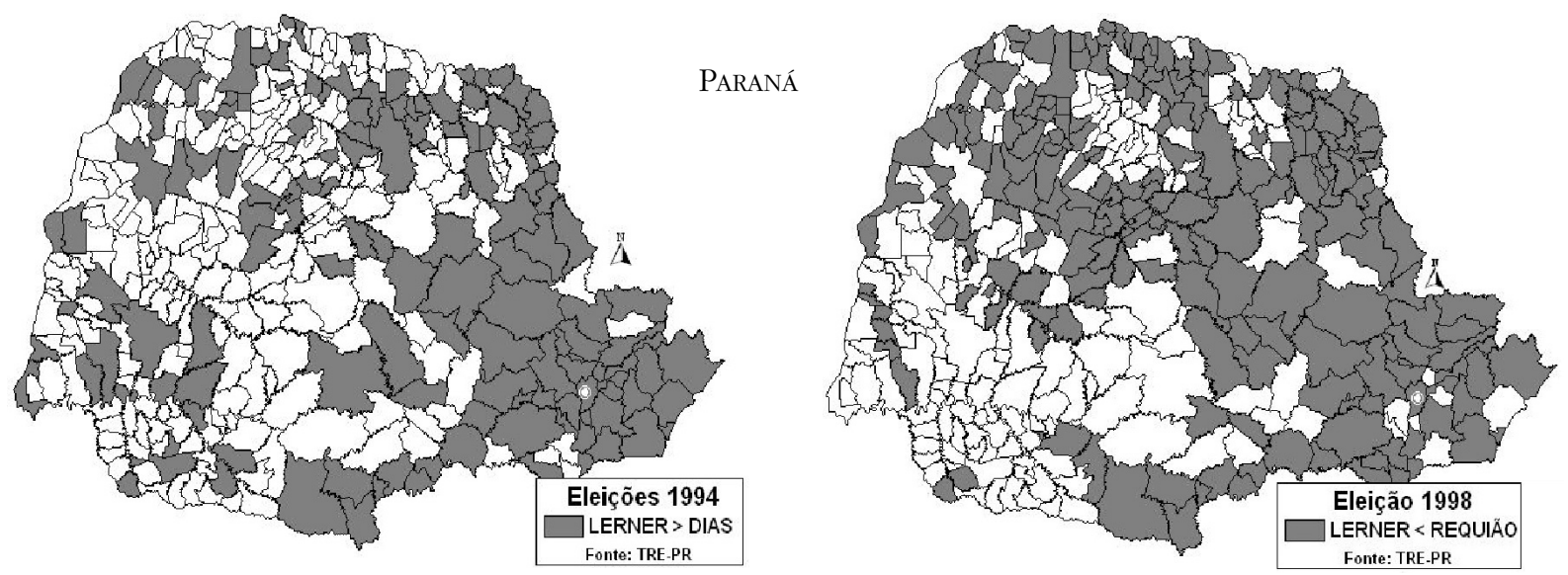
metropolitana como na periférica. Os mapas mostram, todavia, que apesar da semelhança no desempenho eleitoral dos candidatos vencedores, existem diferenças na distribuição espacial dos votos, posicionando, de um lado, o Paraná, e, do outro, a Bahia e o Ceará. No Paraná há uma clara clivagem regional entre os candidatos concorrentes: Lerner teve a preferência dos eleitores das áreas mais urbanizadas e da região no entorno de Curitiba; seus adversários conquistaram a preferência dos eleitores do interior, principalmente nas regiões oeste e norte. Em 1998, essa clivagem fica ainda mais acentuada, como mostra o mapa.

Apesar da distribuição regional dos votos no Paraná ser bastante diferente da dos dois outros estados, essa diferença não invalida o argumento de que os eleitores não rejeitaram os candidatos a governador devido às restrições fiscais por eles impostas. O Paraná aparece, no entanto, como o estado onde existem diferenças nas preferências dos eleitores de cada subcoalizão territorial. $\mathrm{Na}$ Bahia e no Ceará, os vencedores contaram com os votos distribuídos em todo o território estadual, com poucos municípios onde a maioria dos eleitores votou no candidato derrotado. Em ambos os estados, na eleição de 1998, a insatisfação do eleitorado da subcoalizão periférica aumentou ligeiramente, e no Ceará mais do que na Bahia. Assim, confirma-se o argumento de Gibson de que as subcoalizões metropolitana e periférica são igualmente importantes na sustentação de políticas que mudam o status quo, embora, no Paraná, a subcoalizão metropolitana tenha tido maior participação relativa na vitória de Lerner.

Os dados eleitorais também mostram que o eleitorado da Bahia aumentou sua aprovação à coalizão governista entre 1994 e 1998, dado que em 1998 não ocorreu $2^{\circ}$ turno e o candidato da situação recebeu mais votos em 1998 do que em 1994, passando de 58,64\%, em 1994, para 69,91\%, em 1998 e que os vencedores no Ceará e no Paraná conseguiram manter a lealdade de seus eleitores. No Ceará, Jereissati venceu em ambas as eleições com exatamente o mesmo percentual de votos válidos, $55,32 \%$. No Paraná, os votos dados a Lerner diminuíram ligeiramente, de 54,85\%, em 1994, para 52,28\%, em 1998.

O segundo recurso foi construir, para cada estado, seis grupos com o intuito de classificar as diferenças entre os números de votos recebidos pelo candidato vencedor em 1998 e 1994, quais sejam: Grupo 1 - diferenças de votos entre 1998 e 1994 inferior a -10\%; Grupo 2 - diferença de votos entre $-5 \%$ e -10\%; Grupo 3 - diferença de votos entre $-5 \%$ e $5 \%$; Grupo 4 - diferença de votos entre $5 \%$ e 10\%; Grupo 5 - diferença de votos entre $10 \%$ e 15\%; e Grupo 6 - diferença de votos superior a $15 \%$ dos votos. Esse agrupamento permite um teste mais refinado das hipóteses da pesquisa por mostrar as diferenças nos resultados eleitorais de forma mais desagregada do que apenas identificar se o candidato vencedor ganhou ou perdeu mais votos no total de votos recebidos. Permite também uma melhor compreensão das relações entre as diferenças nos resultados eleitorais e as variáveis socioeconômicas. ${ }^{25}$ Esse agrupamento serviu de base para a aplicação dos demais recursos metodológicos que serão detalhados adiante.

O terceiro recurso metodológico foi relacionar os resultados eleitorais a três variáveis: grau de urbanização, IDH-M e gasto per capita dos municípios para cada município dos três estados. Esse recurso permite analisar as relações entre resultados eleitorais (variação da base eleitoral entre 1998 e 1994) e as variáveis socioeconômicas selecionadas. Destaque especial foi dado à variável grau de urbanização, com o objetivo de conhecer melhor o papel das subcoalizões metropolitana e periférica nos resultados eleitorais. Para a análise dessas relações, foram realizados os seguintes procedimentos: (a) análise de correlação - coeficiente de correlação linear de Pearson; (b) análise de regressão (modelo de regressão linear simples); (c) análise de estatísticas descritivas das variáveis socioeconômicas em cada grupo construído; e (d) análise do apoio eleitoral por grau de urbanização. Todas as relações medem apenas a associação entre os indicadores socioeconômicos e os resultados eleitorais nos distritos eleitorais municipais de unidades geográficas dadas, isto é, os municípios da Bahia, do Ceará e do Paraná, que totalizam 912, sendo 419 na Bahia, 184 no Ceará e 309 no Paraná. Dessa forma, a unidade de análise não é o eleitor mas as unidades geográficas. ${ }^{26}$

A aplicação da análise estatística, correlacionando os coeficientes de correlação linear entre a diferença dos resultados eleitorais (1994 e 1998) e as variáveis socioeconômicas utilizadas é apresentada a seguir. 
Tabela 9

BA, CE e PR - Análise de Correlação - Coeficiente de Pearson

\begin{tabular}{|c|c|c|c|c|c|c|c|c|c|c|c|c|}
\hline \multirow[t]{2}{*}{ VARIÁVEIS } & \multicolumn{3}{|c|}{$\begin{array}{l}\text { Gasto PER CAPITA } \\
\text { (GASTOPC) }\end{array}$} & \multicolumn{3}{|c|}{$\begin{array}{c}\text { GRAU URBANIZAÇ̃̃̃O } \\
\text { (GRAURB) }\end{array}$} & \multicolumn{3}{|c|}{ IDH-M } & \multicolumn{3}{|c|}{ Dif. vOTOS** } \\
\hline & BA & $\mathrm{CE}$ & PR & $\mathrm{BA}$ & $\mathrm{CE}$ & PR & $\mathrm{BA}$ & $\mathrm{CE}$ & PR & $\mathrm{BA}$ & $\mathrm{CE}$ & PR \\
\hline GASTO PC & 1,0 & 1,0 & 1,0 & $0,233^{*}$ & $-0,027$ & $-0,074$ & $0,181^{*}$ & $-0,079$ & $-0,258^{*}$ & $-0,052$ & $-0,158^{*}$ & $0,175^{*}$ \\
\hline Graurb & - & - & - & 1,0 & 1,0 & 1,0 & $0,477^{*}$ & $0,342^{*}$ & $0,467^{*}$ & $-0,016$ & $0,199^{*}$ & $-0,15^{*}$ \\
\hline IDH-M & - & - & - & - & - & - & 1,0 & 1,0 & 1,0 & $-0,001$ & 0,093 & $-0,242^{*}$ \\
\hline Dif. votos & - & - & - & - & - & - & - & - & - & 1,0 & 1,0 & 1,0 \\
\hline
\end{tabular}

* Correlação significativa em nível de significância de 0.05 .

**: DIFvotos corresponde à diferença no número de votos dados ao candidato eleito entre 1998 e 1994.

A Tabela 9 indica, no geral, a inexistência de uma associação e/ou dependência considerável que possa ser generalizada para os três estados. Para os municípios da Bahia, os coeficientes de correlação sequer apresentaram significância estatística, ou seja, o coeficiente não é significantemente diferente de zero. No Ceará e no Paraná, apesar de estatisticamente significativas, as correlações apresentaram graus de associação reduzidos, sugerindo a impossibilidade de se indicar um padrão que explique a reação dos eleitores às políticas de ajuste fiscal, assim como relacionar o fato de que os candidatos vencedores conseguiram mais ou menos votos em um dado município às características socioeconômicas do eleitorado. No Paraná, a maior associação foi verificada para a variável IDH $(-0,242)$, seguida da variável gasto per capita $(0,175)$ e grau de urbanização $(-0,15)$, enquanto no Ceará a variável grau de urbanização destacou-se com uma correlação de 0,199, e a variável gasto per capita apresentou um coeficiente de $-0,158$. No Ceará, o coeficiente de correlação linear da variável IDH-M não apresentou significância estatística. Cabe ressaltar que nesses dois estados os sinais dos coeficientes de correlação são opostos.

O resultado da análise de correlação é reforçado pelos resultados das simulações econométricas, as quais pretendem observar a capacidade de se prever valores médios para a variação no número de votos entre 1998 e 1994 a partir de valores fixos das três variáveis de controle, ou seja, as variáveis socioeconômicas. Os resultados das regressões realizadas indicam uma reduzida e insuficiente capacidade explicativa. Além disso, as estatísticas descritivas (mediana e desvio padrão) das variáveis so- cioeconômicas (grau de urbanização, IDH e gasto per capita), realizadas no decorrer da pesquisa e seguindo o agrupamento referido acima, também corroboraram os resultados dos demais instrumentos utilizados.

No que se refere ao suporte eleitoral por grau de urbanização, os dados da Tabela 10 mostram que, na Bahia, o candidato Borges obteve a maioria dos votos nas cinco faixas, apesar de proporcionalmente apresentar melhores resultados à medida que o grau de urbanização é reduzido. No Ceará, por sua vez, o candidato à reeleição obteve a maioria dos votos em todas as faixas, sendo que proporcionalmente Jeressaiti apresentou seu pior desempenho na faixa dos municípios mais urbanizados, o que também ocorreu na Bahia. Como pode ser percebido nessa tabela, e como foi apontado pelo coeficiente de correlação linear, não existe forte relação entre essas variáveis, tendo Jeressaiti obtido proporções semelhantes de suporte eleitoral nas três últimas faixas. No Paraná, a relação é inversa. Lerner obteve a maioria dos votos nas duas faixas que correspondem aos municípios mais urbanizados. Entretanto, essas duas faixas equivalem a $68 \%$ do total de votos. Isso indica que, apesar de haver uma associação negativa entre o grau de urbanização e a diferença de votos entre as duas eleições $(-0,15)$, foram os municípios mais urbanizados que mais contribuíram para a reeleição de Lerner.

Isolando os resultados eleitorais das capitais das dos demais municípios para se ter mais clareza sobre a posição eleitoral da subcoalizão metropolitana, verifica-se que os eleitores de Curitiba sempre apoiaram Lerner, várias vezes seu ex-prefeito, embora em 1998 sua votação tenha sido pro- 
Tabela 10

BA, CE, PR - Apoio Eleitoral por Grau de Urbanização - 1998

\begin{tabular}{|c|c|c|c|c|c|c|c|c|c|}
\hline $\begin{array}{c}\text { GRAU } \\
\text { URBANIZAÇÃOO }\end{array}$ & \multicolumn{3}{|c|}{$\mathrm{N}^{\circ}$ DE MUNICÍPIOS } & \multicolumn{3}{|c|}{$\begin{array}{l}\text { PARTICIPAÇ̃̃O DOS MUNICÍPIOS } \\
\text { NO TOTAL DE VOTOS NO ESTADO }\end{array}$} & \multicolumn{3}{|c|}{$\begin{array}{l}\% \text { DE VOTOS PARA O } \\
\text { CANDIDATO VENCEDOR }\end{array}$} \\
\hline & BAHIA & CEARÁ & Paraná & BAHIA & CEARÁ & Paraná & BAHIA & CEARÁ & PARANÁ \\
\hline$\geqslant 95$ & 8 & 4 & 8 & 28,04 & 36,99 & 33,37 & 59,95 & 54,02 & 56,69 \\
\hline$\geq \geqslant 75<95$ & 51 & 9 & 86 & 24,87 & 8,89 & 34,63 & 71,28 & 72,40 & 50,87 \\
\hline$\geqslant 50<75$ & 123 & 62 & 142 & 19,76 & 25,02 & 18,76 & 74,15 & 66,03 & 48,77 \\
\hline$\geqslant 25<50$ & 177 & 94 & 105 & 22,28 & 25,82 & 11,01 & 75,57 & 67,97 & 47,52 \\
\hline$<25$ & 53 & 15 & 27 & 5,05 & 3,28 & 2,23 & 76,37 & 67,93 & 48,44 \\
\hline TOTAL & 412 & 184 & 358 & 100,00 & 100,00 & 100,00 & & & \\
\hline
\end{tabular}

porcionalmente menor do que em 1994 (neste ano, Lerner obteve $73,02 \%$ dos votos em Curitiba e, em 1998, 60,24\%). Fortaleza, que, em 1994, rejeitou a coalizão liderada por Jereissati, em 1998 lhe dá apoio, com 53,69\% dos votos. Já Salvador votou nas duas eleições nos candidatos governistas, embora com margem relativamente pequena de diferença entre os concorrentes (em 1994, Paulo Souto obteve 55,35\% dos votos e João Durval, 44,65\%; em 1998, César Borges obteve $56,84 \%$ dos votos e os demais candidatos, $43,16 \%$ ). Ou seja, após o ajuste fiscal os eleitores das capitais mantiveram seu apoio aos governadores que o implantaram (Curitiba e Salvador) ou passaram a apoiá-los (Fortaleza). Contudo, os eleitores de Curitiba demonstraram maior apoio ao candidato Lerner do que os eleitores de Salvador e Fortaleza.

Sintetizando, os resultados das eleições em 1994 e em 1998 parecem contestar dois argumentos sobre a política estadual no Brasil. O primeiro é o de que o retorno do voto popular para os Executivos nacional e estadual tenderia a constranger a adoção de políticas macroeconômicas na América Latina. Como ressalta Remmer (1993), os trabalhos que analisam a relação entre política macroeconômica e eleições na América Latina tendem a situar os ciclos eleitorais como momentos de ruptura da política e da gestão macroeconômica em curso. Remmer também mostrou que o impacto das eleições nacionais sobre as políticas macroeconômicas varia muito na América Latina, o que aponta para a necessidade de se ter cautela com generalizações sobre seus resultados e conseqüências. Essas conclusões podem também ser aplicadas aos estados brasileiros.
O segundo argumento refere-se ao foco central desta pesquisa, ou seja, o de que a política estadual é movida por políticas clientelistas e tradicionais, ambas incompatíveis com políticas voltadas para os bens públicos e que mudam o status quo. Esse argumento foi aqui questionado, uma vez que, conforme já mostrado, algumas coalizões políticas estaduais foram capazes de adotar políticas restritivas de gasto e ainda manter o apoio de seus eleitores. Isso leva à possibilidade de se argumentar que, nos estados, as dinâmicas eleitoral e de políticas públicas são muito mais complexas do que tem sido argumentado pela escola do "estado como território puro do clientelismo". A comparação dos resultados dos votos, por município, nas eleições de 1994 antes de ajuste - e 1998 - depois do ajuste - mostra que tem havido uma leitura equivocada ou pelo menos parcial da política estadual após o retorno do voto direto para o Executivo. Isso porque não só os governadores aderiram às políticas restritivas de gasto, como, do ponto de vista territorial, os dados e as análises estatísticas e econométricas mostram que não houve mudança significativa no apoio dado pelos eleitores à coalizão governista que implementou o ajuste fiscal. Ou seja, nos três estados, a base territorial de apoio aos governadores que implantaram o ajuste fiscal não mudou. ${ }^{27}$

\section{Comentários finais}

Este trabalho buscou questionar algumas teses influentes sobre o funcionamento da política estadual, apresentando dados e análises que 
podem fundamentar argumentos alternativos sobre a dinâmica interna das coalizões políticas estaduais que sustentaram eleitoralmente políticas de ajuste fiscal nos estados. Dado o número reduzido de casos analisados, o foco mais nas similaridades do que nas diferenças e as dificuldades operacionais para incluir estados onde a variável dependente fosse distinta da dos três casos aqui analisados, não foi possível construir hipóteses rivais sobre o impacto eleitoral do ajuste fiscal nos estados, como já explicado. No entanto, a pesquisa testou algumas variáveis que podem ser relevantes para a melhor compreensão das conseqüências do ajuste fiscal sobre resultados eleitorais na esfera estadual.

O questionamento das visões mais influentes sobre a política estadual não implica a defesa de que a mesma esteja isenta das características apontadas pelos autores citados, mas sim que a política estadual tem convivido, nos últimos anos, com várias lógicas e conteúdos diversos. O que parece certo é que não apenas uma lógica tem prevalecido na política estadual, ou seja, parecem não existir bases suficientes para afirmar que a política estadual é movida apenas por um leitmotif, tal como o clientelismo e a política tradicional. De acordo com essa literatura, essas lógicas restringiriam a adoção de políticas voltadas para bens públicos e tenderiam a manter políticas que preservam o status quo, principalmente nos estados mais pobres.

As escolhas feitas pelas lideranças políticas da Bahia, do Ceará e do Paraná a favor da adoção de políticas restritivas de gasto mostram que não existem ainda bases sólidas para generalizações sobre o funcionamento da política estadual no Brasil, mas sinalizam no sentido de que a política estadual e suas políticas públicas não são movidas apenas por um leitmotif. Como já mostrado em trabalhos sobre outros temas, a convivência de lógicas aparentemente antagônicas não só é possível como tem sustentado a viabilização de políticas públicas que mudam o status quo, assim como tem permitido a convivência de diferentes arranjos políticos e administrativos na esfera estadual. ${ }^{28}$ Além do mais, a questão-chave desse debate é analisar se a existência de relações clientelistas impede a adoção de políticas mais universais, tais como a de ajuste fiscal. Argumentos da escola "clientelista" retratam a política estadual como estática e movida apenas pelas experiências do passado. Os dados e as análises aqui apresentados, embora limitados a poucos estados, sinalizam que trocas clientelistas não necessariamente bloqueiam ou ameaçam a adoção de políticas restritivas de gasto e que essas políticas não acionaram reações negativas dos eleitores, tanto os que compõem a subcoalizão metropolitana como a periférica.

Essa discussão pode ser resumida em torno de dois pontos principais: (a) a opção pelo entendimento da política estadual como um espaço onde lógicas (ou gramáticas) aparentemente antagônicas podem conviver, em contraposição à defesa de apenas uma lógica modeladora das relações políticas e sociais nos estados; e (b) a opção pelo entendimento de que mudanças no status quo, ao menos nos três estados analisados, não necessariamente afetam antigas alianças eleitorais do ponto de vista territorial, seja se são tomados como unidades de análise todo o território estadual ou os municípios, seja se os eleitores compõem a subcoalização metropolitana ou a periférica, seja, ain$\mathrm{da}$, se a base analítica for as características socioeconômicas dos eleitores.

Algumas coalizões políticas estaduais viabilizaram a adoção e a manutenção de políticas de ajuste fiscal em um ambiente de eleições regulares e competitivas. Obviamente, essas coalizões foram beneficiadas pelo controle que seus políticos exerciam sobre as instituições políticas estaduais, o que lhes permitiu adotar mais livremente políticas restritivas de gasto. Esse controle, no entanto, não parece ser suficiente para explicar como políticas restritivas de gasto puderam ser eleitoralmente viáveis. Isso porque, embora reconhecendo que inúmeras variáveis influenciam os resultados eleitorais, não se pode ignorar que a formação de coalizões políticas para fins eleitorais sofre influência da interseção entre duas dimensões na formação dessas coalizões: a eleitoral e a de políticas públicas. Tais coalizões adaptaram-se às novas "regras do jogo" introduzidas (a) pela redemocratização, que diz respeito à busca de vitórias eleitorais; (b) pelas novas demandas macroeconômicas trazidas pela globalização, que remete a políticas como a do ajuste fiscal; e (c) por um federalismo redesenhado pela redemocratização, que aumentou, em termos relativos, o poder político e tributário dos estados, dando papel relevante às coalizões políticas estaduais nas duas outras dimensões, isto é, nas disputas eleitorais e na 
adoção de políticas restritivas de gasto. Pode-se concluir, portanto, que a política estadual nos casos analisados abriu espaço para a adoção de novas políticas públicas, inclusive algumas vistas como contrárias ao cálculo político de curto prazo, tanto dos eleitores como dos governantes.

\section{Notas}

1 Os poucos trabalhos que analisam a relação entre políticas macroeconômicas e ciclos eleitorais na América Latina focalizam, em geral, as eleições presidenciais. Ver, por exemplo, Remmer (1993) e Gibson (1997).

2 Remmer e Wibbels (2000) e Wibbels (2000) também chamam a atenção para a ausência de pesquisas sobre os efeitos de políticas macroeconômicas na esfera subnacional nos países federais da América Latina. Já a literatura que focaliza os efeitos da descentralização tem sido mais abundante, inclusive produzindo pesquisas que comparam diferentes países da região. Ver, por exemplo, Eaton (2004) e Montero e Samuels (2004).

3 O trabalho pioneiro de Eli Diniz (1982), sobre o funcionamento da máquina política do Rio de Janeiro no período "chaguista", não teve seguimento na agenda de pesquisa no Brasil.

4 Ver, por exemplo, Bonfim (1999), sobre o Ceará; Borges (2000), sobre a Bahia; Desposato (2001), sobre a Bahia, o Piauí, São Paulo, Brasília e Rio Grande do Sul; Schneider (2001), sobre o Rio Grande do Sul, Paraná, a Bahia e Pernambuco; e Souza (1997), sobre a Bahia.

5 A meu ver, a transposição do conceito de clientelismo da antropologia para a ciência política é eivada de problemas. Sobre esse ponto, ver Avelino (1994). Sobre o uso inadequado de conceitos como clientelismo, ver Carvalho (1997).

6 Apesar de Hagopian analisar o papel das elites políticas de Minas Gerais no regime autoritário e nos anos iniciais da redemocratização, sua tese sobre a política estadual (política tradicional) continua muito citada para explicar tanto a atual dinâmica política estadual como a de todos os estados brasileiros.

7 Robinson e Verdier (2001) construíram um modelo para provar que o clientelismo pela via do emprego público tende a ser endêmico nos países em desenvolvimento. O emprego público seria uma estratégia "ótima" nesses países, uma vez que o político não pode assumir compromissos com a adoção de políticas públicas destinadas à produção de bens públicos e à realização de investimentos, porque seus eleitores vivem em situação de alta desigualdade e os países têm baixa produtividade.

8 As transferências federais para estados e municípios movimentam cerca de 8\% do PIB (Afonso, 2004).

9 Na esfera estadual, o ajuste fiscal é a principal ferramenta da política macroeconômica, ao passo que na esfera federal existe um leque mais amplo de políticas de impacto macroeconômico, tais como taxas de juros e de câmbio.

10 Se é verdade que o controle da inflação beneficiou todas as esferas de governo pelo aumento da carga tributária real corrente e alterou o processo inercial de reajustes salariais dos servidores e dos fornecedores, argumento apropriadamente levantado por um dos pareceristas anônimos deste artigo, por outro lado a política de juros altos contribuiu para o aumento exponencial das dívidas estaduais.

11 Para uma análise das tentativas de renegociação das dívidas estaduais anteriores ao Plano Real, ver, entre outros, Almeida (1996) e Souza (1996)

12 As principais medidas foram a Lei Complementar 87, de 13/9/96, e as Leis 9.496 , de 11/9/97, e 10.195, de $14 / 2 / 01$.

13 No primeiro caso, apesar da existência de políticas nacionais restritivas de gasto, as esferas subnacionais podem expandir seus gastos sem que, ao final, tenham que assumir o ônus dessas despesas sozinhas. Já no segundo, existem regras que impedem o socorro financeiro às esferas subnacionais quando o gasto não contar com cobertura orçamentária. Sobre as diferenças entre os dois tipos, ver, entre outros, Rodden, Eskeland e Litvack (2003).

14 A Receita Líquida Real (RLR) é igual à receita total, deduzidas as transferências voluntárias, as operações de crédito, a alienação de bens e as transferências aos municípios.

15 Os contratos são classificados como sigilosos, sendo divulgados apenas dados gerais.

16 Wibbels (2000) classifica o Brasil como um dos países federais onde as instituições políticas e fiscais estimulam os governos subnacionais a não cooperarem com os custos políticos do ajuste fiscal. Ele conclui que em países federais do mundo em desenvolvimento o governo nacional é "forçado a adotar reformas macroeconômicas altamente restriti- 
vas, ao passo que os governos das províncias evitam esforços desse tipo" [tradução minha]. Essa conclusão não se aplica aos estados brasileiros desde o final dos anos de 1990.

17 As exceções foram o Rio de Janeiro e o Distrito Federal.

18 A maioria desses critérios também se aplica ao estado de São Paulo. Sua exclusão da amostra deve-se à ausência de trabalhos acadêmicos analisando a política estadual paulista recente e a dificuldade para a coleta de dados eleitorais desagregados por município, uma vez que esses dados não estavam disponíveis à época do processamento dos dados da pesquisa nos sítios dos tribunais eleitorais.

19 Como se vê, os três estados apresentam mais similaridades do que diferenças. Como mostra Peters (1998, p. 37), explicar similaridades ou diferenças pode nos dizer muito sobre como os governos funcionam. No entanto, os estados selecionados não apresentam diferenças tanto na variável dependente (resultados eleitorais) como na independente (ajuste fiscal rigoroso), o que limita o conhecimento sobre os fatores que podem produzir diferenças, assim como se os estados onde a coalizão que implantou o ajuste fiscal foi derrotada apresentam padrão semelhante ou não no que se refere, por exemplo, ao apoio das subcoalizões metropolitanas e periféricas. Na fase de definição dos casos, foram identificados outros estados como "ideais" para contrapor aos três aqui estudados. São os casos, por exemplo, de Pernambuco e Rio Grande do Sul, estados que apresentam as maiores diferenças no que se refere às suas dinâmicas político-eleitorais vis-àvis os três estados aqui analisados, e que contam também com características "ideais" para uma comparação em termos regionais. As razões da sua exclusão foram as mesmas do estado de São Paulo. Assim, a seleção dos estados seguiu apenas parcialmente a linha metodológica de autores como King et al. (1994, p. 221), que advogam que a seleção de casos das esferas subnacionais para pesquisas comparadas deve incluir apenas aqueles nos quais a hipótese da pesquisa seja passível de teste, analisando-se, contudo, não só casos similares, mas também os diferentes em relação às variáveis. As vantagens de explorar comparações entre esferas subnacionais de governo para o melhor entendimento das mudanças nos processos políticos e econômicos vêm sendo apontadas por diversos autores, como, por exemplo, Snyder (2001). Essa vantagem é ainda mais relevante em países com altos níveis de heterogeneidade interna como o Brasil, e os estados selecionados refletem, embora de forma incompleta e apenas nas variáveis de controle, a heterogeneidade socioeconômica brasileira.

20 Em 2006, venceu, na Bahia, o candidato do PT, Jacques Wagner, e no Ceará, o do PSB, Cid Gomes, derrotando os candidatos do PFL e do PSDB que concorriam à reeleição.

21 Dados detalhados sobre as despesas estaduais podem ser acessados no site http://www.stn. fazenda.gov.br/.

22 Um dos pareceristas anônimos deste artigo levantou a questão sobre o caráter voluntário ou não do ajuste por parte dos governadores.

23 Uma diferença entre as bases constitutivas da pesquisa de Gibson e as desta pesquisa está na sustentação do populismo na Argentina e no México, e do clientelismo, no Brasil. Nos primeiros, essa base estaria nas áreas urbanas e, no Brasil, segundo muitos autores, disseminado em todo território estadual, embora, para os brasilianistas, mais concentrado nos estados que contam com eleitores pobres e desorganizados.

24 Mapas elaborados no software Maptitude, versão 4.5.

25 Devo a Fernando Limongi a sugestão para esse agrupamento.

26 Os dados foram levantados nas seguintes fontes: IBGE, para o grau de urbanização; Nepp/ Unicamp, para receita per capita municipal; Ipea/PNUD, para o IDH-M; e Tribunais Regionais Eleitorais da Bahia, Ceará e Paraná, coletados diretamente em suas sedes, para os resultados eleitorais por município.

27 Futuras pesquisas devem aprofundar a investigação do impacto do ajuste fiscal sobre o gasto público total, em especial os gastos com investimentos e com programas sociais A desagregação dos gastos permitirá conhecer melhor onde foram concentrados os cortes de despesa. Seria também necessário investigar o impacto da transferência de recursos federais para programas sociais administrados pelos municípios, que cresceram significativamente no final dos anos de 1990, em especial as transferências do SUS. Com essas transferências, os estados podem ter sido liberados de alguns encargos financeiros, agora assumidos pelos municípios e financiados principalmente por recursos federais, mas também assumiram maiores encargos financeiros na área de educação, a partir da institucionalização do Fundef. Nos casos da Bahia e do Ceará, programas de combate à pobreza também injetaram nos 
municípios recursos federais e de organismos multilaterais administrados pelos estados.

28 Souza (1997) demonstrou, na análise do sistema político da Bahia, a convivência, dentro do aparelho de Estado, de lógicas clientelistas que se materializam nas agências estaduais voltadas para a área social, com lógicas burocrático-autoritárias e de insulamento burocrático nas agências voltadas para as atividades econômicas, de planejamento e de finanças públicas. Tendler (2000) argumenta na mesma direção em relação ao desempenho dos chamados fundos sociais financiados pelo Banco Mundial. Na esfera federal, a convivência de lógicas aparentemente antagônicas no aparelho administrativo foi demonstrada por Nunes (1997), em sua análise sobre o que chamou de quatro gramáticas do funcionamento da administração pública federal.

\section{BIBLIOGRAFIA}

ABRUCIO, Fernando L. (1998), Os barões da federação: os governadores e a redemocratização brasileira. São Paulo, Hucitec.

AFONSO, José Roberto. (2004), "Brasil, um caso à parte". Trabalho apresentado no XVI Regional Seminar on Fiscal Policy, Santiago, 15 jan.

(2006), "Proteção social e novos desafios para a descentralização fiscal: o caso brasileiro". Trabalho apresentado no $18^{\circ}$ Seminário Regional de Política Fiscal, Santiago, 26 jan.

ALMEIDA, Anna Ozório. (1996), Evolução e crise da dívida pública estadual. Brasília, Ipea.

AMES, Barry. (1996), "Electoral rules, constituency pressures, and pork barrel: bases of voting in the Brazilian Congress". Journal of Politics, 57: 324-243.

. (2001), The deadlock of democracy in Brazil. Ann Arbor, The University of Michigan Press.

AVELINO FILHO, George. (1994), "Clientelismo e política no Brasil: revisitando velhos problemas". Novos Estudos CEBRAP, 38: 225-240.

BLANCO, Fernando Andrés. (s/d), "Comportamento fiscal dos governos estaduais brasileiros: determinantes políticos e efeitos so- bre os indicadores socioeconômicos dos seus estados". Rio de Janeiro (datilo.).

BONFIM, Washington. (1999), Qual mudança? Os empresários e a americanização do Ceará. Tese de doutorado, Rio de Janeiro, Iuperj (datilo.).

BORGES, André. (2000), A retórica da eficiência: as políticas de ajuste fiscal na Babia. Dissertação de mestrado, Salvador, NPGA/ Universidade Federal da Bahia (datilo.).

CARVALHO, José Murilo de. (1997), "Mandonismo, coronelismo, clientelismo: uma discussão conceitual. Dados, 20 (2): 229-250.

DANTAS NETO, Paulo Fábio. (2003), "Surf nas ondas do tempo: do carlismo histórico ao carlismo pós-carlista". Caderno CRH, 39: 213-256.

DESPOSATO, Scott. (2001), Institutional theories, societal realities, and party politics in Brazil. Tese de doutorado. Los Angeles, University of California (datilo.).

DINIZ, Eli. (1982), Voto e máquina política: patronagem e clientelismo no Rio de Janeiro. Rio de Janeiro, Paz e Terra.

EATON, Kent. (2004), Politics beyond the capital: the design of subnational institutions in South America. Stanford, Stanford University Press.

GIBSON, Edward. (1997), "The populist road to market reform policy and electoral coalitions in Mexico and Argentina". World Politics, 49 (3): 339-370.

GIBSON, Edward \& CALVO, Ernesto. (2000), "Federalism and low-maintenance constituencies: territorial dimensions of economic reform in Argentina". Studies in Comparative International Development, 35 (3): 526-599.

HAGOPIAN, Frances. (1996), Traditional politics and regime change in Brazil. Cambridge, Cambridge University Press.

KING, Gary; KEOHANE, Robert \& VERBA, Sydney. (1994), Designing social inquiry: scientific inference in qualitative research. Princeton, NJ, Princeton University Press. 
KUGELMAS, Eduardo. (2001), "A evolução recente do regime federativo no Brasil", in W. Hofmeister e J. M. Brasiliense Carneiro (orgs.), Federalismo na Alemanha e no Brasil, São Paulo, Konrad Adenauer.

LORA, Eduardo. (2000), What makes reforms likely? timing and sequencing of structural reforms in Latin America. Washington, DC, InterAmerican Development Bank (datilo.).

MAINWARING, Scott. (1999), Retbinking party systems in the third wave of democratization: the case of Brazil. Stanford, Stanford University Press.

MELO, Marcus André. (2005), "O sucesso inesperado das reformas de segunda geração: federalismo, reformas constitucionais e política social". Dados, 48 (4): 845-889.

MONTERO, Alfred \& SAMUELS, David J. (eds.). (2004), Decentralization and democracy in Latin America. Notre Dame, University of Notre Dame Press.

MORA, Mônica. (2002), Federalismo e divida estadual no Brasil. Rio de Janeiro, Ipea.

NUNES, Edson. (1997), A gramática política do Brasil. Brasília/Rio de Janeiro, Enap/Jorge Zahar.

OLIVEIRA, Nelson. (2000), "Sob o manto da concórdia: Bahia como contrafação do moderno", in N. Oliveira et al. (orgs.), A outra face da moeda, Salvador, Comissão de Justiça e Paz da Arquidiocese de Salvador.

PETERS, Guy. (1998), Comparative politics: theory and methods. Houndmills, Palgrave.

REMMER, Karen L. (1993), "The political economy of elections in Latin America, 1980-1991". American Political Science Review, 87 (2): 393-407.

REMMER, Karen \& WIBBELS, Erik. (2000), "The subnational politics of economic adjustment: provincial politics and fiscal performance in Argentina". Comparative Political Studies, 33 (4): 419-451.

RIGOTON, Francisco \& GIAMBIAGI, Fabio. (1998), Renegociação das dividas estaduais: um novo regime fiscal ou a repetição de uma antiga bistória?. Rio de Janeiro, Ipea (datilo.).

ROBINSON, James \& VERDIER, Thierry. (2001), "The political economy of clientelism". Berkeley, Departments of Political Science and Economics, University of California (datilo.).

RODDEN, Jonathan. (2003), "Federalism and bailouts in Brazil", in J. Rodden, G. Eskeland \& J. Litvack (eds.), Fiscal decentralization and the challenge of hard budget constraints, Cambridge, Cambridge University Press.

RODDEN, J, ESKELAND, G. \& LITVACK, J. (eds.). (2003), Fiscal decentralization and the challenge of hard budget constraints. Cambridge, Cambridge University Press.

SAMUELS, David J. \& MAINWARING, Scott. (2004), "Strong federalism, constraints on the central government, and economic reform in Brazil", in E. Gibson (ed.), Federalism and democracy in Latin America, Baltimore/ Londres, The Johns Hopkins University Press.

SCHNEIDER, Aaron. (2001), Federalism against markets: local struggles for power and national fiscal adjustment in Brazil. Tese de doutorado, University of California at Berkeley (datilo.).

SNYDER, Richard. (2001), "Scaling down: the subnational comparative method". Studies in Comparative International Development, 36 (1): 93-110.

SOUZA, Celina. (1996), "Redemocratization and decentralization in Brazil: the strength of the member states". Development and Change, 27 (3): 529-555.

. (1997), Constitutional engineering in Brazil: the politics of federalism and decentralization. Houndmills/Londres/Nova York, Macmillan/St. Martin's Press.

. (2001), "Federalismo e descentralização na Constituição de 1988: processo decisório, conflitos e alianças". Dados, 44 (3): $513-560$.

TENDLER, Judith. (2000), "Why are social funds so popular?", in Y. Shahid, W. Weiping e S. 
Everett (eds.), Local dynamics in the era of globalization, Oxford, Oxford University Press for the World Bank.

TER-MINASSIAN, T. \& CRAIG, J. (1997), "Control of subnational government borowwing", in $\mathrm{T}$. Ter-Minassian (ed.), Fiscal federalism in theory and practice, Washington, D.C., IMF.

WEYLAND, Kurt. (1996), Democracy without equity: failures of reform in Brazil. Pittsburg, University of Pittsburg Press.

WIBBELS, Erik. (2000), "Federalism and the politics of macroeconomic policy and performance". American Journal of Political Science, 44 (4): 687-702. 


\section{COALIZÕES ELEITORAIS E AJUSTE FISCAL NOS ESTADOS BRASILEIROS}

Celina Souza

Palavras-chave: Política estadual; Ajuste fiscal; Coalizões eleitorais.

Em países federais redemocratizados e que assumiram o ajuste fiscal como prioridade, os estados passaram a jogar um papel importante no controle das contas públicas. Este artigo discute o impacto de políticas restritivas de gasto sobre os resultados eleitorais para o Executivo estadual e questiona a hipótese de que a política estadual no Brasil é movida apenas por lógicas clientelistas, pela manutenção de políticas que não afetam o status quo (política tradicional) e pelo uso dos recursos públicos para sustentá-las. Argumento que a política estadual é influenciada por lógicas diversas, as quais permitem aos políticos estaduais conciliarem a adoção de políticas restritivas de gasto com vitórias eleitorais. Três estados foram selecionados para testar essas hipóteses: Bahia, Ceará e Paraná.

\section{ELECTORAL COALITIONS AND FISCAL ADJUSTMENT IN BRAZILIAN STATES}

Celina Souza

Keywords: State politics; Fiscal adjustment; Electoral coalitions.

In federal countries that have reinstated the popular vote for state governors and in which fiscal adjustment is a priority, the states have become important players in fiscal control. The article analyzes the impact of policies of hard budget constraints on the electoral results for state governors and challenges the hypothesis that state politics in Brazil are moved by clientelism, by policies not affecting the status quo (traditional politics) and by the use of public resources to sustain them. I argue that state politics in Brazil is driven by several rationales. Different rationales give room for state politicians to adopt fiscal policies and still be reelected or elect their candidates for governorship. Three states have been selected to test these hypotheses: Bahia, Ceará, and Paraná.

\section{LES COALITIONS ÉLECTORALES ET RÈGLEMENT FISCAL DANS LES ÉTATS BRÉSILIENS}

Celina Souza

Mots-clés : Politique des États; Règlement fiscal; Coalitions électorales.

Les États, dans les pays fédéraux redémocratisés et qui ont assumé le règlement fiscal comme une question prioritaire, jouent désormais un rôle important dans le contrôle des comptes publics. Cet article discute l'impact des politiques restrictives de dépenses sur les résultats électoraux pour le pouvoir exécutif des États et questionne l'hypothèse selon laquelle la politique des États au Brésil est menée uniquement par des logiques clientélistes, par le maintien de politiques qui n'affectent pas le status quo (la politique traditionnelle) et par l'usage de ressources publiques pour les maintenir. Je défends que la politique des États est influencée par diverses logiques qui permettent aux politiciens de ces États de concilier l'adoption de politiques restrictives de dépenses avec des victoires électorales. Trois États ont été sélectionnés pour tester ces hypothèses: Bahia, Ceará et Paraná. 